\title{
HOSPITAL-BASED SEROPREVALENCE AMONG SUSPECTED CASES OF DENGUE IN A TERTIARY CARE HOSPITAL
}

\author{
Deepali Dilip Belurkar1, Poonam Chanderlal Sharma², Poorva Abhishek Sule ${ }^{3}$ \\ 1 Professor and HOD, Department of Microbiology, Rajiv Gandhi Medical College, Thane. \\ ${ }^{2}$ Assistant Manager, Department of Pharmacovigilance, Tata Consultancy Services, Thane. \\ ${ }^{3}$ Lecturer, Department of Microbiology, Rajiv Gandhi Medical College, Thane.
}

\section{ABSTRACT}

\section{BACKGROUND}

Dengue has been one of the most important public health issues in tropical and subtropical regions of the world due to the spread of the vector infestation in domestic environments and the potential of dengue virus infection to cause successive epidemics in highly urbanised settings. This retrospective observational study was undertaken to determine the occurrence of dengue in clinically suspected patients in and around Thane so as to be able to formulate strategies to combat this menace.

\section{MATERIALS AND METHODS}

Blood samples were collected from 1986 clinically suspected Dengue Fever (DF) or Dengue Haemorrhagic Fever (DHF) cases attending a tertiary care health centre in a metropolitan city from September 2015 to August 2016. Sera were tested for dengue specific IgM and IgG antibodies by immunochromatographic strip.

\section{RESULTS}

Out of 1986 patients, 479 were seropositive for dengue antibodies, prevalence being $24.12 \%$. Amongst seropositive cases, $46.35 \%$ were IgM positive. Besides these, $31.73 \%$ were also positive for both IgM and IgG while $21.92 \%$ were only IgG positive.

\section{CONCLUSION}

Dengue is becoming an emerging problem in Thane. Hence, diagnosis at an early stage is the effective strategy to control disease progression.

\section{KEYWORDS}

Dengue, Dengue Fever (DF), Dengue Haemorrhagic Fever (DHF), IgM, IgG, Prevalence.

HOW TO CITE THIS ARTICLE: Belurkar DD, Sharma PC, Sule PA. Hospital-based seroprevalence among suspected cases of dengue in a tertiary care hospital. J. Evolution Med. Dent. Sci. 2017;6(49):3777-3780, DOI: 10.14260/Jemds/2017/816

\begin{abstract}
BACKGROUND
Dengue has been one of the most important public health issues in tropical and subtropical regions of the world due to the spread of the vector infestation in domestic environments and the potential of dengue virus infection to cause successive epidemics in highly urbanised settings. ${ }^{1}$ According to the World Health Organization (WHO), there are about 390 million cases of dengue fever worldwide, and of the total number of cases, 96 million require medical treatment. India also saw a doubling up of cases of dengue from 2014 to 2015 and the worst hit city was Delhi with over 1800 cases of the fever. 2016 was not expected to be any better and this has become a cause of concern for the country. ${ }^{2}$ In light of the potential for continued expansion of dengue globally, it is essential to reflect on policy and strategic direction that attempts to reduce the impact of this disease. ${ }^{3}$
\end{abstract}

Financial or Other, Competing Interest: None.

Submission 03-05-2017, Peer Review 08-06-2017,

Acceptance 13-06-2017, Published 19-06-2017.

Corresponding Author:

Dr. Deepali Dilip Belurkar,

Professor and HOD,

Department of Microbiology,

Rajiv Gandhi Medical College and

Chhatrapati Shivaji Maharaj Hospital,

Thane-Belapur Road,

Kalwa, Thane-400605.

E-mail: drbelurkar@gmail.com

DOI: $10.14260 /$ jemds $/ 2017 / 816$

(c) $($ ) $\$$
Among cities in Maharashtra, the reported number of dengue cases in 2014 in Thane was only second to Greater Mumbai. ${ }^{4}$ Experts stated that $77 \%$ outbreak of dengue was reported from Thane, Pune and Nashik division in $2015 .{ }^{5}$

In Maharashtra state, the vector borne disease is no longer concentrated in urban areas and is spreading to small towns and villages, the reason being rapid urbanisation of small towns. ${ }^{4}$ Hence, we also included patients from adjoining Thane suburban areas like Kalwa, Mumbra, Diva, etc.

\section{Objective}

This study was undertaken to determine the occurrence of dengue in clinically suspected patients in and around Thane so as to be able to formulate strategies to combat this menace.

\section{MATERIALS AND METHODS}

This retrospective, observational study was conducted in a tertiary care hospital in Thane city of Maharashtra for a period of one year from September 2015 to August 2016. Since this study used secondary data, implied consent of the patient was sought.

\section{Inclusion Criterion}

Any patient with acute febrile illness with some of the symptoms like myalgia, arthralgia, headache, retro-orbital pain, bleeding, skin rash, altered sensorium, shock or low platelet count were included in the study. Dengue 
haemorrhagic fever (DHF) and Dengue shock syndrome (DSS) were defined as per WHO criteria. ${ }^{6}$

\section{Sample Collection and Processing}

Blood samples were collected from 1986 patients attending the tertiary care hospital who were clinically suspected to be suffering from DF or DHF. Sera were separated and tested for dengue specific IgM and IgG antibodies by immunochromatographic strip procured from SD Bioline. The kit has a sensitivity of $94.6 \%$ and specificity of $96.5 \%{ }^{7}$

\section{RESULTS}

Out of 1986 patients, 479 were seropositive for dengue antibodies, prevalence being $24.12 \%$. But maximum prevalence was seen during the post-monsoon period in months of September to December 2015 i.e. 303 out of 479 cases. So period wise overall cases were statistically highly significant at $0.01 \%$ i.e., $\mathrm{P}<0.001$ as seen in Table 1 .

\begin{tabular}{|c|c|c|c|c|c|c|c|}
\hline \multirow{2}{*}{$\begin{array}{c}\text { Months } \\
(2015-16)\end{array}$} & \multirow{2}{*}{$\begin{array}{c}\text { Months in } \\
\text { each Period }\end{array}$} & \multicolumn{3}{|c|}{ Dengue (\%) } & \multirow{2}{*}{$\begin{array}{c}\text { Chi Square } \\
\text { Test }\end{array}$} & \multirow{2}{*}{ P-value } & \multirow{2}{*}{$\begin{array}{c}\text { Significant at } \\
5 \% \text { Level }\end{array}$} \\
\hline & & -ve & $+\mathrm{ve}$ & Total & & & \\
\hline $\begin{array}{l}\text { September } 2015 \text { to } \\
\text { December } 2015\end{array}$ & 4 & $598(66.4 \%)$ & $303(33.6 \%)$ & $901(100 \%)$ & \multirow{4}{*}{116.192} & \multirow{4}{*}{$<0.001$} & \multirow{4}{*}{ Yes } \\
\hline $\begin{array}{c}\text { January } 2016 \text { to April } \\
2016\end{array}$ & 4 & $370(93.9 \%)$ & $24(6.1 \%)$ & $394(100 \%)$ & & & \\
\hline May 2016 to August 2016 & 4 & $539(78.0 \%)$ & $152(22.0 \%)$ & $691(100 \%)$ & & & \\
\hline Total & 12 & $\begin{array}{c}1507 \\
(75.9 \%)\end{array}$ & $479(24.1 \%)$ & $1986(100 \%)$ & & & \\
\hline
\end{tabular}

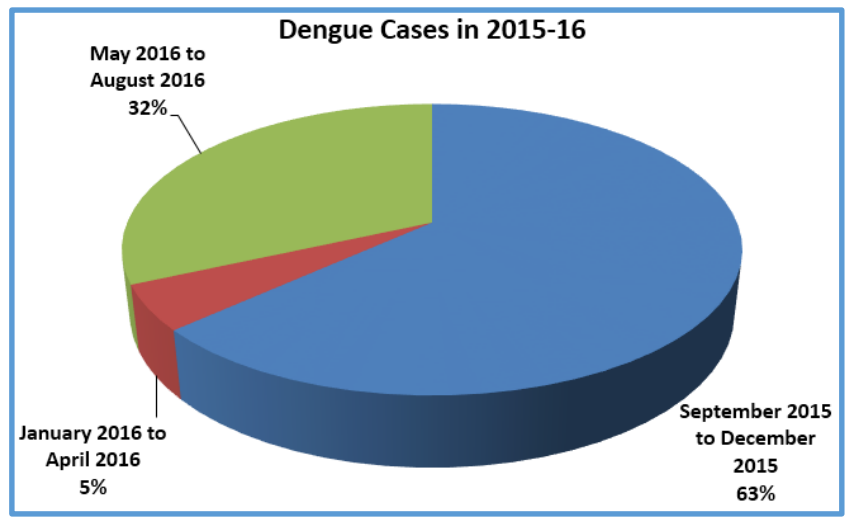

Figure 1. Prevalence of Dengue from September 2015 to August 2016

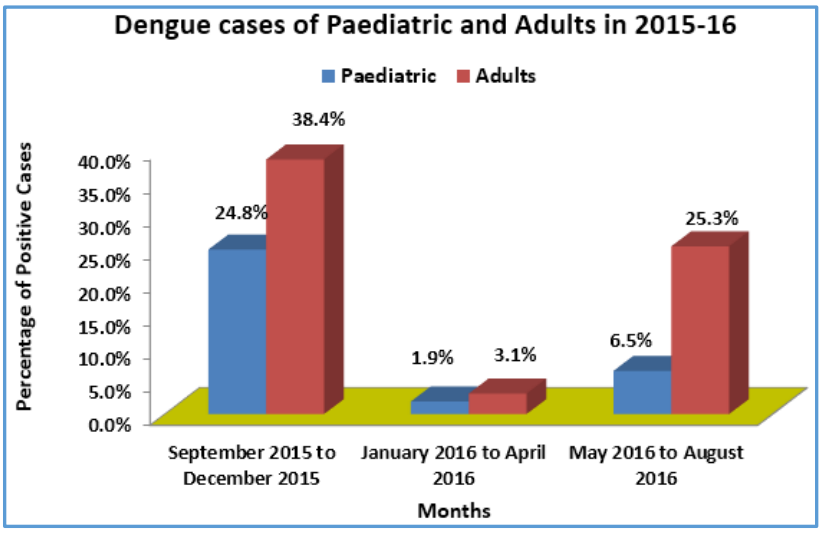

Figure 2. Prevalence of Dengue in Paediatric and Adult Group

Table 2 shows the prevalence cases of dengue in Paediatric as well as Adults group which is statistically highly significant at $0.01 \%$ i.e. $\mathrm{P}<0.001$

\begin{tabular}{|c|c|c|c|c|c|c|c|}
\hline \multirow{2}{*}{$\begin{array}{c}\text { Months } \\
(2015-16)\end{array}$} & \multirow{2}{*}{$\begin{array}{c}\text { Months in } \\
\text { each Period }\end{array}$} & \multicolumn{3}{|c|}{ Dengue (\%) } & \multirow{2}{*}{$\begin{array}{c}\text { Chi Square } \\
\text { Test }\end{array}$} & \multirow{2}{*}{ P-value } & \multirow{2}{*}{$\begin{array}{l}\text { Significant } \\
\text { at } 5 \% \text { Level }\end{array}$} \\
\hline & & Paediatric +ve & Adults +ve & Total & & & \\
\hline $\begin{array}{l}\text { September } 2015 \text { to } \\
\text { December } 2015\end{array}$ & 4 & 119 (24.8\%) & $184(38.4 \%)$ & $303(63.3 \%)$ & \multirow{4}{*}{16.48} & \multirow{4}{*}{$<0.001$} & \multirow{4}{*}{ Yes } \\
\hline $\begin{array}{c}\text { January } 2016 \text { to } \\
\text { April } 2016\end{array}$ & 4 & $9(1.9 \%)$ & $15(3.1 \%)$ & $24(5.0 \%)$ & & & \\
\hline $\begin{array}{l}\text { May } 2016 \text { to } \\
\text { August } 2016\end{array}$ & 4 & $31(6.5 \%)$ & $121(25.3 \%)$ & $152(31.7 \%)$ & & & \\
\hline Total & 12 & $159(33.2 \%)$ & $320(66.8 \%)$ & $479(100 \%)$ & & & \\
\hline
\end{tabular}

Table 3 shows the sex-wise prevalence of Dengue in the adult group is not statistically significant at $5 \%$ level i.e., $\mathrm{P}>0.05$. Thus, the distribution of male and female dengue cases in different periods is proportionally similar.

\begin{tabular}{|c|c|c|c|c|c|c|c|}
\hline \multirow{2}{*}{$\begin{array}{c}\text { Months } \\
(2015-16)\end{array}$} & \multirow{2}{*}{ Months } & \multicolumn{3}{|c|}{ Adults Dengue (\%) } & \multirow{2}{*}{\begin{tabular}{|c|} 
Chi Square \\
Test
\end{tabular}} & \multirow{2}{*}{$\begin{array}{c}\text { P- } \\
\text { value }\end{array}$} & \multirow{2}{*}{$\begin{array}{c}\text { Significant at } \\
5 \% \text { Level }\end{array}$} \\
\hline & & Male +ve & Female +ve & Total & & & \\
\hline $\begin{array}{l}\text { September } 2015 \text { to } \\
\text { December } 2015\end{array}$ & 4 & $91(28.4 \%)$ & $93(29.1 \%)$ & $184(57.5 \%)$ & \multirow{4}{*}{4.338} & \multirow{4}{*}{0.114} & \multirow{4}{*}{ No } \\
\hline January 2016 to April 2016 & 4 & $7(2.2 \%)$ & $8(2.5 \%)$ & $15(4.7 \%)$ & & & \\
\hline May 2016 to August 2016 & 4 & $74(23.1 \%)$ & $47(14.5 \%)$ & $121(37.8 \%)$ & & & \\
\hline Total & 12 & $172(53.8 \%)$ & $148(46.3 \%)$ & $320(100 \%)$ & & & \\
\hline
\end{tabular}




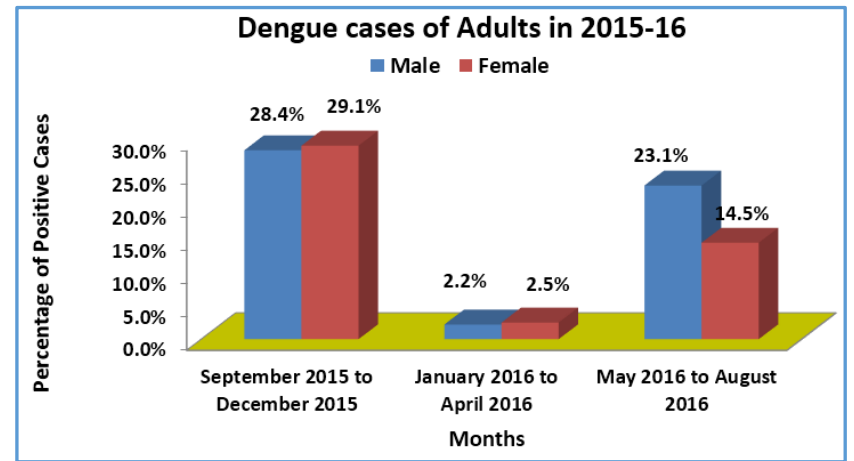

Figure 3. Sex-wise Prevalence of Dengue in Adult Group
Table 4 shows that amongst the positive cases, $46.35 \%$ were IgM positive which indicated recent dengue infection. Out of these, $31.73 \%$ were also positive for both IgM and IgG indicating convalescent phase. Besides these, 21.92\% were only IgG positive which showed past infection with dengue. Rest of the other patients showed clinical manifestations of dengue with even low platelet counts, but the serology was negative probably due to early investigations for antibody detection.

\begin{tabular}{|c|c|c|c|c|c|c|}
\hline Month & $\begin{array}{c}\text { Total Suspected } \\
\text { Cases }\end{array}$ & IgM only & IgG only & IgM+ IgG & $\begin{array}{c}\text { Total Seropositive } \\
\text { Cases }\end{array}$ & Prevalence \\
\hline Sep. 2015 & 276 & 43 & 25 & 35 & 103 & $37.32 \%$ \\
\hline Oct. 2015 & 254 & 35 & 16 & 46 & 97 & $38.19 \%$ \\
\hline Nov. 2015 & 251 & 36 & 20 & 28 & 84 & $33.47 \%$ \\
\hline Dec. 2015 & 120 & 9 & 8 & 2 & 19 & $15.83 \%$ \\
\hline Jan. 2016 & 74 & 2 & 0 & 4 & 6 & $8.12 \%$ \\
\hline Feb. 2016 & 105 & 4 & 0 & 3 & 7 & $6.67 \%$ \\
\hline Mar. 2016 & 75 & 0 & 3 & 0 & 3 & $4.00 \%$ \\
\hline Apr. 2016 & 140 & 2 & 2 & 4 & 8 & $5.71 \%$ \\
\hline May 2016 & 163 & 3 & 3 & 13 & 19 & $11.66 \%$ \\
\hline Jun. 2016 & 58 & 8 & 2 & 4 & 14 & $24.14 \%$ \\
\hline Jul. 2016 & 190 & 20 & 10 & 2 & 32 & $16.84 \%$ \\
\hline Aug. 2016 & 280 & 60 & 16 & 11 & 87 & $31.07 \%$ \\
\hline Total & 1986 & $222(46.35 \%)$ & $105(21.92 \%)$ & $152(31.73 \%)$ & $479(100 \%)$ & $24.12 \%$ \\
\hline \multicolumn{7}{|c|}{ Table 4: Monthly Distribution of Seropositive Cases based on Detection of Antibody } \\
\hline
\end{tabular}

\section{DISCUSSION}

Dengue has been classified as a 'neglected tropical disease,' based on the historical lack of coordinated efforts, political will, and research attention despite the significant disease, social, and economic burden it places internationally. Many experts hypothesise that dengue will increase in the future, including geographic expansion, incidence and reporting to WHO. ${ }^{3}$

Since our laboratory was mainly concerned with clinical diagnosis, we used immunochromatographic method which has the advantage of rapidity. In facilitating early diagnosis by using this Dengue Rapid Test, therapy and monitoring can begin much earlier, reducing the risk of severe complications. ${ }^{8}$ The other available test in our laboratory was Dengue IgM Microlisa which is only a screening test. ${ }^{9}$ Keeping in mind the type of laboratory facilities and technical expertise available, costs, and the time of sample collection, ${ }^{10}$ we employed rapid diagnostic test.

In our study, the seroprevalence of dengue is $24.12 \%$ which is similar to study conducted by Raut et al.11 Maximum prevalence was seen during the post-monsoon period in months of September to December 2015 which is concurrent to most of the previous outbreaks in India and maybe because this time period is a very favourable season for high breeding of the vector Aedes aegypti. ${ }^{12,13}$ The male to female ratio was $1.16: 1$ which is similar to the studies by other researchers. ${ }^{14}$ But it was not statistically significant in our study. However, few other studies show a slightly higher male preponderance.11,15 We could not find any paediatric preponderance in our study. Adults were more commonly affected than children. Other Indian studies have reported young adults as the most affected age group. ${ }^{12,13,16}$

The number of samples positive for dengue virus-specific IgM antibodies was 222 (46.35\%). Out of this, 31.73\% were also positive for IgG. Besides these, $21.92 \%$ were only IgG positive. Study by Singhal et al has also reported the similar findings. ${ }^{17}$

\section{Limitations of the Study}

Our study is a hospital-based study and hence may not characterise the whole population. Increasing awareness, quality diagnostic resources, accessibility of more sensitive and specific diagnostic tests can affect reporting pattern to some level.

\section{CONCLUSION}

The high rate of detection reported here i.e. $24.12 \%$ of clinically suspected patients indicates that dengue is becoming an emerging problem in Thane city and surrounding areas. Hence, it is essential to consider policy and strategic direction that will help to decrease the burden of this disease. Diagnosis of dengue at an early stage is the effective strategy to control disease progression. Also, preventive measures against dengue infection should be vigorous during water stagnation periods and at the end of monsoon.

\section{ACKNOWLEDGMENT}

The authors are thankful to the teaching and technical staff of Department of Microbiology, Rajiv Gandhi Medical College and Chhatrapati Shivaji Maharaj Hospital, Kalwa. 


\section{REFERENCES}

[1] Argolo AF, Feres VC, Silveira LA, et al. Prevalence and incidence of dengue virus and antibody placental transfer during late pregnancy in central Brazil. BMC Infectious Diseases 2013;13:254.

[2] Soni S. Dengue 2016. Here's all you need to know. Health news. The times of India 2016. http://timesofindia.indiatimes.com/life-style/healthfitness/health-news/Dengue-2016-Heres-all-youneed-to-know/articleshow/52533932.cms

[3] Murray NE, Quam MB, Wilder-Smith A. Epidemiology of dengue: past, present and future prospects. Clin Epidemiol 2013;5(1):299-309.

[4] Isalkar U. Small towns and villages account for 3/4th of dengue cases in state. http://epaperbeta.timesofindia.com/Article.aspx?eid= 31814\&articlexml=Small-towns-and-villages-accountfor-34th-of-15072014002021.

[5] FPJ Bureau. Dengue: Maharashtra reports 174 cases this year.

http://www.freepressjournal.in/mumbai/denguemaharashtra-reports-174-cases-this-year/780208

[6] World Health Organization. Dengue, dengue haemorrhagic fever and dengue shock syndrome in the context of the integrated management of childhood illness. Geneva: WHO. 2017. http://apps.who.int/iris/bitstream/10665/69230/1/ WHO_FCH_CAH_05.13_eng.pdf

[7] Standard diagnostics, inc. SD Bioline Dengue IgG/IgM. http://www.standardia.com/en/home/product/Rapi d_Diagnostic_Test/Anti-Dengue_IgGIgM.html 2017.

[8] WordPress. Popular dengue elisa kits \& dengue rapid tests-FAQ.

http://rapidtest.com/blog/category/rapidtests/deng ue-rapid-tests/ 2017.
[9] J Mitra \& Co Pvt Ltd., Dengue IgM Microlisa. http://jmitra.co.in/download/Procedure/ManualDengueIgMMicrolisa.pdf 2017.

[10] Geneva: World Health Organization. Dengue: guidelines for diagnosis, treatment, prevention and control: new edn. 2017. https://www.ncbi.nlm.nih.gov/books/NBK143156/

[11] Raut S, Patil A. Dengue in and around Nagpur- Central India. Journal of Evolution of Medical and Dental Sciences 2012;1(5):853-6.

[12] Ukey PM, Bondade SA, Paunipagar PV, et al. Study of seroprevalence of dengue fever in central India. Indian J Community Med 2010;35(4):517-9.

[13] Gupta E, Dar L, Narang P, et al. Serodiagnosis of dengue during an outbreak at a tertiary care hospital in Delhi. Indian J Med Res 2005;121(1):36-8.

[14] Kamath S, Jain N, Gupta S, et al. Dengue epidemic in Jamshedpur-Tata Main Hospital (TMH) experience. J Trop Dis Pub Health 2015;3(2):159.

[15] Nepal HP, Ansari S, Gyawali N, et al. Detection of IgM against dengue virus in clinically suspected patients presenting at a tertiary care centre, Narayani Zone, Nepal. J Trop Dis 2014;2(3):139.

[16] Kumar A, Rao CR, Pandit V, et al. Clinical manifestation and trend of dengue cases admitted in tertiary care hospital, Udupi District, Karnataka. Ind J Comm Med 2010;35(3):386-90.

[17] Singhal S, Varshney KR, Mittal V, et al. Seroprevalence of dengue in tertiary care centre at Lucknow. Journal of Evolution of Medical and Dental Sciences 2013;2(21):3726-30. 